Editorial

\title{
AGCP: who are we?
} \author{
Associação Gaúcha de Coloproctologia

\footnotetext{
${ }^{1}$ Associação Gaúcha de Coloproctologia, Hospital de Clínicas de Porto Alegre, Porto Alegre, RS, Brazil

2 Associação Gaúcha de Coloproctologia, Universidade Católica de Pelotas, Pelotas, RS, Brazil

${ }^{3}$ Associação Gaúcha de Coloproctologia, Hospital Moinhos de Vento, Porto Alegre, RS, Brazil

${ }^{4}$ Associação Gaúcha de Coloproctologia, Hospital de Clínicas de Porto Alegre, Porto Alegre, RS, Brazil

5 Associação Gaúcha de Coloproctologia, Universidade Federal de Ciências da Saúde de Porto Alegre, Porto Alegre, RS, Brazil
}

Tiago Leal Ghezzi ${ }^{1}$ Marcelo de Alexandre Britto ${ }^{2}$ José Luiz Barbieux ${ }^{3}$ Ignacio Osorio Mallmann ${ }^{4}$ Denise Fattore ${ }^{3 \oplus}$ Karen Delacoste Pires Mallmann ${ }^{5}$ On behalf of the

J Coloproctol 2021;41(3):215-216.

The Brazilian Society of Coloproctology (SBCP, in the Portuguese acronym) is a not-for-profit medical association with the objective of bringing together Brazilian physicians dedicated to this specialty. ${ }^{1}$ The SBCP currently consists of eight regional units ${ }^{1}$ with the Associação Gaúcha de Coloproctologia (AGCP, in the Portuguese acronym) being the oldest unit The AGCP originated in the Department of Proctology of the Medical Association of Rio Grande do Sul (AMRIGS, in the Portuguese acronym), founded on March 16, 1967.,3 In 1991, it was converted into the Sociedade de Coloproctologia do Rio Grande do Sul ${ }^{2,3}$ and, in 2009, it became the AGCP. ${ }^{4}$ Located in Porto Alegre, state of Rio Grande do Sul (RS), Brazil, the AGCP has the objectives of bringing together coloproctologists from RS, issuing opinions on subjects related to the specialty, representing the scientific and professional interests of its members, promoting scientific activities, and representing the specialty with the AMRIGS and SBCP. ${ }^{2}$

To identify the demographic and professional profile of coloproctologists in RS, the AGCP proposed to conduct a research titled "AGCP: who are we?". The purpose of this investigation was to identify and compare the demographic and professional profiles of AGCP member and non-member coloproctologists. All professionals currently active in RS were included, with a coloproctologist being considered a physician who met one of the following criteria: (1) having undergone a 2-year medical residency in a coloproctology service recognized by the Ministry of Education; (2) having undergone a 2-year apprenticeship in a Coloproctology Service recognized by the SBCP, or a 4-year clinical fellowship in a coloproctology service (after 1980), or a 2-year clinical fellowship as a full SBCP member (before 1980), followed by approval in the SBCP board certification. The research population was identified using the SBCP online register, AGCP physical and historical files, Google, and a list of former residents of coloproctology services in RS. Of the 244 names identified, 79 were excluded for the following reasons: not currently working in RS (34), not considered a coloproctologist (10), retired (19), or dead (16). The final study sample included 165 physicians. Interestingly, there was an equal number of coloproctologists who studied in RS and worked outside the state (34 in total, 22 in the state of Santa Catarina, Brazil) and coloproctologists who studied in other states ( 34 in total, 13 in the state of São Paulo, Brazil) and worked in RS. The survey tool, Google Forms, was used to create a questionnaire comprising 35 objective questions sent via e-mail between January and August 2020. Members and non-members of the AGCP were compared regarding the following demographic and professional variables: gender, age, city of birth and domicile, type of coloproctology training (medical residency, apprenticeship, or clinical fellowship), coloproctology training status, being an SBCP member, specialist title by SBCP, stricto sensugraduate program, working sector (public and/or private), working in coloproctology (anorectal surgery, abdominal surgery, or colonoscopy), teaching activity, other acting area (general surgery, management/administration, medical audit, and others), practice of minimally invasive surgery (laparoscopic, transanal endoscopic, or robotic), treatment of choice for anal condylomatosis, collection of anal
Address for correspondence Tiago Leal Ghezzi, MD, MSc, PhD, Hospital de Clínicas de Porto DOI https://doi.org/

Alegre, Porto Alegre, Rio Grande do Sul, Brazil

(e-mail: tiagoghezzi@gmail.com). 10.1055/s-0041-1730427. ISSN 2237-9363. (c) 2021. Sociedade Brasileira de Coloproctologia. All rights reserved. This is an open access article published by Thieme under the terms of the Creative Commons Attribution-NonDerivative-NonCommercial-License, permitting copying and reproduction so long as the original work is given appropriate credit. Contents may not be used for commercial purposes, or adapted, remixed, transformed or built upon. (https://creativecommons.org/ licenses/by-nc-nd/4.0/)

Thieme Revinter Publicações Ltda., Rua do Matoso 170, Rio de Janeiro, RJ, CEP 20270-135, Brazil 
cytology, experience in anoscopy with magnification, performing anorectal manometry, experience with sacral neuromodulation, approach to inflammatory bowel disease (IBD) (alone or multidisciplinary), experience with IBD drugs (aminosalicylates, corticoids, immunosuppressants, and biologicals), preferred age of starting colorectal cancer screening (CCS), preferred screening colonoscopy periodicity in case of normal examination, and preferred techniques for surgical treatment of hemorrhoidal disease, anal fissure, complex anal fistula, and sacrococcygeal pilonidal disease.

The initial (voluntary) response rate to the questionnaire was of $63 \%$, reaching $100 \%$ after telephonic follow-up of nonresponders. Out of the 165 participants, 95 (57.6\%) were AGCP members and 70 (42.4\%) were non-members. Considering the 2020 Brazilian Institute of Geography and Statistics (IBGE, in the Portuguese acronym) population estimate of 11,377,239 inhabitants in RS, the mean density was 68,952 inhabitants per coloproctologist in the state. The 3 microregions with the highest density of inhabitants per coloproctologist were Ijuí $(38,383)$, Porto Alegre $(41,830)$, and Passo Fundo $(51,346)$. The 3 cities with the highest densities were Carlos Barbosa (14,916), Ijuí (16,695), and Porto Alegre $(18,318)$. Although the active coloproctologists RS are still predominantly men (66\% versus $34 \%$ ), women have started to predominate (65\% versus 35\%) after 2010 . The mean age of the coloproctologists in RS is 47.3 years old, with $84 \%$ being up to 60 years old. Medical residency is the main training modality in coloproctology (90\%), mostly (81\%) performed in RS. Regarding affiliation, 78\% were SBCP members and 52\% were AGCP members.

The comparison of demographic and professional data showed a statistically significant difference between AGCP members and non-members in the following variables: gender (male, 56.8 versus $78.6 \%$; $p=0.006$ ), domicile in Porto Alegre (55.8 versus $38.6 \% ; p=0.042)$, SBCP member $(84.2$ versus $70 \% ; p=0.046)$, specialist title by the SBCP $(64.2$ versus $47.1 \% ; p=0.042$ ), performing laparoscopic surgery (80 versus $62.9 \% ; p=0.023$ ), experience with sacral neuromodulation ( 13.7 versus $2.9 \% ; p=0.034$ ), and age to start CCS at 45 years old ( 78.9 versus $50 \% ; p=0.001$ ) and at 50 years old (16.8 versus $40 \% ; p=0.001$ ).

The present editorial presents a simple but accurate representation of the current panorama of coloproctology in RS, showing demographic profile and professional performance differences between AGCP member and nonmember coloproctologists. We believe this initiative can be extremely interesting and important if implemented nationwide by the SBCP.

Conflict of Interests

The authors have no conflict of interests to declare.

\section{References}

1 Website da Socidade Brasileira de Coloproctologia. https://sbcp. org.br/) acessado em 20 de novembro de 2020

2 Cerato NL, Cerato MM. 50 years of the Colorectal Society of RS (AGCP). J Coloproctol (Rio J) 2017;37(03):171-173

3 Associação Gaúchade ColoproctologiaAta de Assembléia Geral Extraordinária. $1^{\circ}$ Serviço de Registro Civil das Pessoas Jurídicas de Porto Alegre. Folha 4, 1588359, Adriano Barragam Staubus, Francesca Perondi, Éder Vieira Flores 10 de março de 2009

4 Estatuto da Associação Gaúcha de Coloproctologia. $1^{\circ}$ Serviço de Registro Civil das Pessoas Jurídicas de Porto Alegre. Folha 5, 1588359, Adriano Barragam Staubus, Francesca Perondi, Éder Vieira Flores 10 de março de 2009 